THE FALL OF LANGUAGE 



\title{
THE FALL OF LANGUAGE
}

\author{
Benjamin and Wittgenstein on Meaning
}

\author{
ALEXANDER STERN
}

$\theta$

\author{
11 \\ II \\ Harvard University Press \\ Cambridge, Massachusetts \\ London, England \\ 2019
}


Copyright $\odot 2019$ by the President and Fellows of Harvard College All rights reserved

Printed in the United States of America

First printing

Jacket art: Albrecht Dürer, The Expulsion from Paradise, 1510, woodcut, Rosenwald Collection, National Gallery of Art, Washington, D.C.

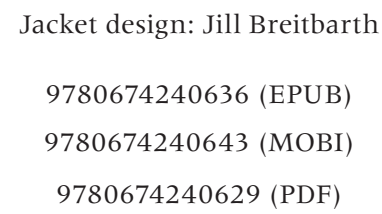

The Library of Congress has cataloged the printed edition as follows:

Names: Stern, Alexander, author.

Title: The fall of language : Benjamin and Wittgenstein on meaning / Alexander Stern.

Description: First edition. I Cambridge, Massachusetts : Harvard University Press, 2019. I Includes bibliographical references and index.

Identifiers: LCCN 2018039155 I ISBN 9780674980914 (hardcover : alk. paper)

Subjects: LCSH: Benjamin, Walter, 1892-1940. I Wittgenstein, Ludwig, 1889-1951. I Language and languages-Philosophy. I Meaning (Philosophy) Classification: LCC P107 .S737 2019 | DDC 401-dc23 LC record available at https://lccn.loc.gov/2018039155 